\title{
SOURCES AND CONCENTRATIONS OF CUPRIC FUNGICIDES FOR THE CONTROL OF CITRUS BLACK SPOT ${ }^{1}$
}

\author{
DANILO FRANCO ${ }^{2 *}$, ANTONIO DE GOES ${ }^{2}$, FERNANDA DIAS PEREIRA $^{2}$
}

\begin{abstract}
Citrus black spot (CBS) is a severe disease for citriculture in the São Paulo State, Brazil. Part of its management is focused on chemical control using cupric fungicides and strobilurins. The objective of the present work was to evaluate the efficacy of three sources and three concentrations of cupric fungicides (copper hydroxide, copper oxychloride and cuprous oxide). Orange fruits of the Pera cultivar were bagged in the plants and the treatment with cupric fungicide was applied. The fruits were inoculated (by spray) with Phyllosticta citricarpa $\left(1 \times 10^{4}\right.$ conidia $\left.\mathrm{mL}^{-1}\right)$ after $0,7,14,21$, and 28 days, and bagged again. The evaluation of incidence and severity was did at the harvest time of fruits. A second experiment was conducted under natural infection with the same treatments, consisting of application of fungicides at the stages F1 (petal fall) and F2 (fruits with diameter of $1 \mathrm{~cm}$ ), using mechanized sprayer with mean flow of $7.35 \mathrm{~L}$ solution plant ${ }^{-1}$. Subsequently, all treatments received four applications of azoxystrobin $\left(30 \mathrm{~g} \mathrm{ha}^{-1}\right)$, plus mineral oil at $0.25 \%$. Four monthly evaluations were done to determine the CBS incidence and severity. The initial applications with cupric fungicides are essential for the control of CBS; the fungicide copper hydroxide showed the best control of CBS

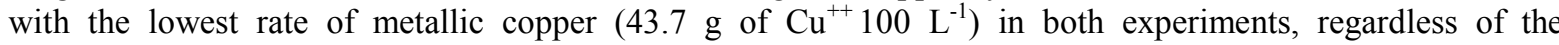
conduction conditions.
\end{abstract}

Keywords: Citrus sinensis. Phyllosticta citricarpa. Metallic copper.

\section{FONTES E CONCENTRAÇÕES DE FUNGICIDAS CÚPRICOS NO CONTROLE DA MANCHA PRETA DOS CITROS}

RESUMO - A mancha preta dos citros é uma doença severa para a citricultura do Estado de São Paulo. Parte do seu manejo é focado no controle químico usando fungicidas cúpricos e estrobilurinas. Este trabalho teve o objetivo de avaliar a eficácia de três fontes e três concentrações de fungicidas cúpricos (hidróxido de cobre, oxicloreto de cobre e óxido cuproso). Frutos de laranjeira 'Pera' foram ensacados nas plantas seguido de tratamento com fungicida cúprico. Posteriormente, após zero; sete; 14; 21 e 28 dias tais frutos foram inoculados com Phyllosticta citricarpa (1x104 conídios mL-1), por pulverização, seguido de novo ensacamento. A avaliação da incidência e severidade da doença ocorreu na colheita dos frutos. Um segundo experimento, sob infecção natural, foi constituído pelos mesmos tratamentos, sendo os fungicidas aplicados nos estádios F1 (queda de pétalas) e F2 (frutos com 1cm de diâmetro) mediante pulverização tratorizada e vazão média 7,35 L calda planta-1. Subsequentemente, e de forma semelhante para todos os tratamentos, foram realizadas quatro aplicações de azoxistrobina (30 g de i.a./ha) acrescida de óleo mineral a 0,25\%. Foram realizadas quatro avaliações mensais para determinação da incidência e severidade dos sintomas. Concluiu-se que: as pulverizações iniciais com fungicidas cúpricos são fundamentais para o controle da mancha preta dos citros; independente das condições de condução, para ambos os ensaios o fungicida hidróxido de cobre propiciou a melhor resposta de controle da mancha preta dos citros com a menor dosagem de cobre metálico $(43,7 \mathrm{~g}$ de $\mathrm{Cu}++100 \mathrm{~L}-1)$.

Palavras-chave: Citrus sinensis. Phyllosticta citricarpa. Cobre metálico.

\footnotetext{
*Corresponding author

${ }^{1}$ Received for publication in $01 / 09 / 2018$; accepted in 09/23/2019.

Paper extracted from the doctoral thesis of the first author.

${ }^{2}$ Department of Phytossanity, Universidade Estadual Paulista, Jaboticabal, SP, Brazil; franco.danilo@gmail.com - ORCID: 0000-00033331-974X, adggoes@yahoo.com.br - ORCID: 0000-0002-7749-3523, fe.eng.agronomica@gmail.com - ORCID: 0000-0002-6280-1562.
} 


\section{INTRODUCTION}

Citrus black spot (CBS) is caused by the fungus Phyllosticta citricarpa McAlp. (teleomorph: Guignardia citricarpa Kiely) (BALDASSARI; WICKERT; GOES, 2008), and is associated with citrus plants in several countries in Africa, Asia, Oceania (KOTZÉ, 2000; EPPO, 2017), South America and North America, and in Caribe (TIMMER et al., 2000; SCHUBERT et al., 2010; HIDALGO and PÉREZ, 2010). All citrus varieties of economic importance are susceptible to this fungus, with losses that can reach $40 \%$ of the production (SILVA JÚNIOR et al., 2016).

The control of CBS is done usually by using fungicides; in Brazil, it is controlled mainly with use of cupric and strobilurin fungicides (MOTTA, 2009; VINHAS, 2011; SILVA JÚNIOR et al., 2016). Cupric fungicides are commonly applied after petal fall, corresponding to the stages F1 and F2, until the fruits reach diameter of $1 \mathrm{~cm}$ (STOLLER, 2010;), followed by two to five applications of strobilurin fungicides (SCALOPPI et al., 2012), covering the more susceptible period for fruits (AGUIAR et al., 2012), from petal fall until the end of the summer, when rainfall periods of more than 8 hours still occur. Ikeda (2011) reported satisfactory responses of control of CBS to the use of five or six applications of cupric fungicides combined or alternated with strobilurins.

Cupric fungicides are approved, for citrus plants, only for the control of citrus scab and melanosis, except copper hydroxide (Kocide WDG Bioactive, Mitsui \& Co. Brasil, S.A.) (BRASIL, 2017); however, they are used isolate or in combination with strobilurins for the control of $P$. citricarpa (VINHAS, 2011). These fungicides are applied with four-week intervals, beginning after $3 / 4$ of petals felled, and subsequently with 28-day intervals, combined with application of strobilurins at 35-day to 42-day intervals (MOTTA, 2009). The recommended rates of cupric fungicides are 0.75 to $1.25 \mathrm{~g} \mathrm{~L}^{-1}$ for copper hydroxide, $2.5 \mathrm{~g} \mathrm{~L}^{-1}$ for copper oxychloride, and $1.0 \mathrm{~g} \mathrm{~L}^{-1}$ for cuprous oxide (BRASIL, 2017). However, the rates used at the stages $\mathrm{F} 1$ and F2, and in subsequent applications in combination with strobilurins for the control of CBS under field conditions vary, and are usually based on the fungicide metallic copper contents. These recommendations are from studies with copper oxychloride; no studies comparing sources and concentrations of cupric fungicides are found.

In this context, the objective of the present work was to evaluate the efficacy of three sources and three concentrations of cupric fungicides under artificial conditions of inoculation with $P$. citricarpa, and under natural conditions, to determine the equivalence between the different compounds in relation to metallic copper concentration in the solution.

\section{MATERIAL AND METHODS}

\section{Experiment I - Protector effect for different sources and rates of cupric fungicides against Phyllosticta citricapa infection in orange fruits of the Pera cultivar}

The experiment was conducted in 2012 in an orchard with orange plants of the Pera cultivar (plant spacing of $5.5 \times 2 \mathrm{~m}$ ), at a private property in Olímpia, state of São Paulo (SP), Brazil $\left(20^{\circ}\right.$ 41'57.23"S and 48 59'35.33"W).

The isolated pathogen was from Conchal, SP, Brazil. It was multiplied in Petri dishes containing BDA medium and maintained in BOD at temperature of $25^{\circ} \mathrm{C}$.

The fungicides evaluated were copper hydroxide (Kocide WDG Bioactive ${ }^{\mathbb{R}} 462 \mathrm{~g}$ of copper hydroxide, Mitsui \& Co. Brasil, S.A.), copper oxychloride $\left(\right.$ Recop $^{\circledR} 840 \mathrm{~g}$ of copper oxychloride, Atanor do Brasil), and cuprous oxide (Redshield $750^{\circledR} 750 \mathrm{~g}$ of cuprous oxide, Agrovant Comércio de Produtos Agrícolas Ltda). The treatments and rates used are shown in Table 1.

Approximately 5,000 fruits at stage F2 (STOLLER, 2010) of 100 plants were bagged on $02 / 23 / 2015$ to avoid infections by $P$. citricarpa naturally presents in the area. When the plants were at stage F4, they were treated with cupric fungicide on 05/13/2016. Subsequently, the fruits were inoculated with $P$. citricarpa $\left(1 \times 10^{4}\right.$ conidia $\left.\mathrm{mL}^{-1}\right)$ in intervals of $0,7,14,21$, and 28 days. The inoculum was prepared and the inoculation was done according to the methodology described by Almeida; Reis; Goes, et al. (2008). After inoculation, the fruits were bagged again, using double layer bags (crystal paper), according to the methodology adopted by Motta (2009). The fruits were kept in the bag until the harvest (10/31/2016).The fungicides were applied according to an adaption of the method of Motta (2009); fruits with diameter of 40 to $50 \mathrm{~mm}$ were individually sprayed with fungicide, plus mineral oil at $0.20 \%\left(\mathrm{v} \mathrm{v}^{-1}\right)$.

A completely randomized experimental design was used, with a $3 \times 3 \times 5$ factorial arrangement consisted of three fungicides, three rates, and 5 inoculation times, with four replications. The plots consisted of 20 fruits. The control treatment consisted of fruits without application of cupric fungicide and with artificial inoculation with $P$. citricarpa. 
Table 1. Description of the cupric fungicide treatments for the control of citrus black spot in orange plants of the Pera cultivar, and their active ingredient concentrations, formulated product rates, and metallic copper equivalent rates.

\begin{tabular}{lccc}
\hline \multirow{2}{*}{ Treatments } & Concentration & \multicolumn{2}{c}{ Rate per 100 liters of solution } \\
\cline { 3 - 4 } & $\mathrm{g} \mathrm{kg}^{-1}$ & $\begin{array}{c}\text { Formulated } \\
\text { Product }\end{array}$ & Metallic Copper \\
\hline Copper hydroxide $\left(538 \mathrm{~g} \mathrm{~kg}^{-1}\right)$ & 538 & 125.0 & 43.7 \\
Copper hydroxide $\left(538 \mathrm{~g} \mathrm{~kg}^{-1}\right)$ & 538 & 100.0 & 35.0 \\
Copper hydroxide $\left(538 \mathrm{~g} \mathrm{~kg}^{-1}\right)$ & 538 & 75.0 & 26.2 \\
Copper oxychloride $\left(840 \mathrm{~g} \mathrm{~kg}^{-1}\right)$ & 840 & 200.0 & 100.8 \\
Copper oxychloride $\left(840 \mathrm{~g} \mathrm{~kg}^{-1}\right)$ & 840 & 180.0 & 90.7 \\
Copper oxychloride $\left(840 \mathrm{~g} \mathrm{~kg}^{-1}\right)$ & 840 & 135.0 & 68.0 \\
Cuprous oxide $\left(860 \mathrm{~g} \mathrm{~kg}^{-1}\right)$ & 860 & 120.0 & 90.0 \\
Cuprous oxide $\left(860 \mathrm{~g} \mathrm{~kg}^{-1}\right)$ & 860 & 75.0 & 56.3 \\
Cuprous oxide $\left(860 \mathrm{~g} \mathrm{~kg}^{-1}\right)$ & 860 & 56.3 & 42.2 \\
Control & & & \\
\hline
\end{tabular}

Copper hydroxide $=$ Kocide WDG Bioactive ${ }^{\circledR}$, Mitsui \& Co. Brasil, S.A.; Copper oxychloride $=$ Recop ${ }^{\circledR}$, Atanor do Brasil; and Cuprous oxide $=$ Redshield $750^{\circledR}$, Agrovant Comércio de Produtos Agrícolas Ltda.

The evaluations consisted of determination of the incidence (\%) of symptomatic fruits for citrus black spot (CBS), and the disease severity. The CBS severity was estimated using a scale of grades, according to visual symptoms in percentage of lesion area $-0=$ fruits without visual symptoms, $1=$ up to $0.8 \%, 2=0.8 \%$ to $1.6 \%, 3=1.6 \%$ to $3.1 \%, 4=3.1 \%$ to $6.2 \%, 5=6.2 \%$ to $12.5 \%, 6=$ more than $6.2 \%$ (SPÓSITO et al., 2004).

The grades attributed to fruits were used to determine the disease index (DI), according to Wheeler (1969):

$$
D I=\frac{1}{N} \sum_{i=0}^{m} i . n_{i}
$$

were $N$ is the number of total fruits evaluated, $i$ is the grade of the fruit, $n i$ is the number of fruits with grade $I$, and $m$ is the maximum grade.

The grades attributed, disease index, and the other parameters were subjected to analysis of variance, and the means were compared by the ScottKnott test at 5\% probability of error.

\section{Experiment II - Evaluation of rates of cupric fungicides for the control of citrus black spot}

The experiment was conducted in 2007, under natural conditions of infection by $P$. citricarpa, in an orchard with orange plants of the Pera cultivar (plant spacing of $7 \times 3.5 \mathrm{~m}$ ), at a private property of commercial production in Olímpia, SP, Brazil $\left(20^{\circ}\right.$ 47'59.17"S, 49²'34.94"W).

The treatments evaluated in this experiment, representing the cupric fungicide variations, were the same used in Experiment I (Table 1).

The fungicides were applied using a mechanized sprayer (FM Copling) with 54 nozzles MagnoJet-DDC4, diffusers 25 with $758.42 \mathrm{kPa}$ at 540 RPM, power takeoff with 1900 RPM, and tractor speed of $3.4 \mathrm{~km} \mathrm{~h}^{-1}$. The mean flowrate was $7.35 \mathrm{~L}$ plant $^{-1}$, equivalent to $134 \mathrm{~mL} \mathrm{~m}^{-3}$ on the plants' canopies. The cupric fungicides were sprayed when the plants were at the stages F1 and F2 (STOLLER, 2010 ), on $12 / 02 / 2015$ and $12 / 23 / 2015$. The spraying of fungicides were resumed on 01/13/2016 with foliar applications of $500 \mathrm{~g}$ of azoxystrobin $\left(\right.$ Vantigo $^{\mathbb{R}}$, Syngenta Proteção de Cultivos Ltda, São Paulo) at concentration of $16 \mathrm{~g}$ per $100 \mathrm{~L}$ of water plus mineral oil $\left(\right.$ Agefix $^{\circledR}$, Packblend Indústria e Comércio de Lubrificantes Ltda) at $0.25 \%\left(\mathrm{v} \mathrm{v}^{-1}\right)$ until $05 / 19 / 2016$, totaling four applications with 42 day intervals.

A randomized block experimental design was used, consisting of 10 treatments and four replications. The plots consisted of three rows of 11 plants, totaling 33 plants or $808.5 \mathrm{~m}^{2}$.

The evaluations were carried out on 08/10/2016, 09/08/2016, 10/06/2016, and 11/14/2016 to determine the CBS incidence and severity in 100 random fruits collected from the five central plants of each plot. The CBS severity was estimated using a scale of grades (SPÓSITO et al., 2004), and the data were used to determine the disease index (DI), according to the same equation used in Experiment I.

The DI data were used to determine the area under the disease progress curve (AUDPC) by the trapezoidal method (DI1 + DI2)/2*(Day2 - Day1). The fruits were harvested on $11 / 30 / 2016$, when the fruit yield per plant $(\mathrm{kg})$ was determined. The data were subjected to analysis of variance and the means were compared by the Scott-Knott test at 5\% probability of error. The data were also subjected to regression analysis to determine the rates of each fungicide based on linear and quadratic responses of the AUDPC.

\section{RESULTS AND DISCUSSION}




\section{Experiment I}

All treatments with the highest rates of cupric fungicides presented on average lower incidence and severity of citrus black spot (CBS) (Table 2). The results showed direct and significant responses between fungicide rates and CBS incidence and severity, except for the treatment with copper oxychloride at $90.7 \mathrm{~g} 100 \mathrm{~L}^{-1}$. However, high rates on equivalent metallic copper do not necessarily mean high concentrations of fungicide (SILVA JÚNIOR et al., 2016).

The number of days after the application of fungicides had a significant and negative effect, with lower CBS incidence and severity when the inoculation with Phyllosticta citricarpa and the treatment was carried out on the same day. The inoculations between 7 and 28 days after the fungicide application resulted in similar protections. This result is related to those reported by Motta (2009), who found incidence of $30 \%$ and $80 \%$ when the inoculation was at 1 and 28 days after application of copper oxychloride, respectively. Thus, the methodology used is efficient to evaluate and replicate results, and can be used to evaluate new formulations or fungicides.

The interaction between the fungicide rates, fungicide sources, and days after treatment of fruits was not significant, denoting that the protection tends to decrease over time at the same proportion for all the treatments, even when using different fungicide rates and sources. These results showed that the best interval between applications of cupric fungicides depends on the control level desired, in terms of CBS incidence and severity. Thus, it can be weekly for production of fruits with lower incidence, and up to 28 days for production of fruits with incidence and severity within limits that avoid the fall of fruits. Motta (2009) found similar results, with increases in CBS incidence and severity as a function of increases in the intervals between the application of copper oxychloride and artificial inoculation with $P$. citricarpa; they reported satisfactory protection up to 21 days after the application.

Table 2. Incidence and disease index of citrus black spot (Phyllosticta citricarpa) in orange fruits of the Pera cultivar as a function of cupric fungicides rates and sources and days after the application, in the 2015/2016 crop season.

\begin{tabular}{|c|c|c|c|c|}
\hline Sources of variation & & Incidence (\%) & Disease index & \\
\hline \multicolumn{5}{|c|}{ Rate ( $\mathrm{g}$ of metallic } \\
\hline \multicolumn{5}{|c|}{ 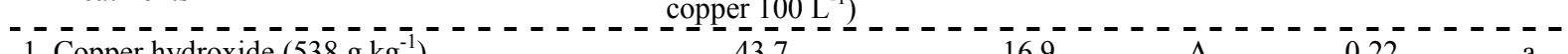 } \\
\hline 2. Copper hydroxide $\left(538 \mathrm{~g} \mathrm{~kg}^{-1}\right)$ & 35.0 & 24.5 & 0.31 & \\
\hline 3. Copper hydroxide $\left(538 \mathrm{~g} \mathrm{~kg}^{-1}\right)$ & 26.2 & 26.5 & 0.34 & \\
\hline 4. Copper oxychloride $\left(840 \mathrm{~g} \mathrm{~kg}^{-1}\right)$ & 100.8 & 14.7 & 0.19 & \\
\hline 5. Copper oxychloride $\left(840 \mathrm{~g} \mathrm{~kg}^{-1}\right)$ & 90.7 & 13.0 & 0.17 & \\
\hline 6. Copper oxychloride $\left(840 \mathrm{~g} \mathrm{~kg}^{-1}\right)$ & 68.0 & 32.5 & 0.41 & \\
\hline 7. Cuprous oxide $\left(860 \mathrm{~g} \mathrm{~kg}^{-1}\right)$ & 90.0 & 17.9 & 0.24 & \\
\hline 8. Cuprous oxide $\left(860 \mathrm{~g} \mathrm{~kg}^{-1}\right)$ & 56.3 & 20.8 & 0.27 & 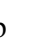 \\
\hline 9. Cuprous oxide $\left(860 \mathrm{~g} \mathrm{~kg}^{-1}\right)$ & 42.2 & 38.9 & 0.49 & 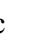 \\
\hline \multirow{2}{*}{\multicolumn{5}{|c|}{ 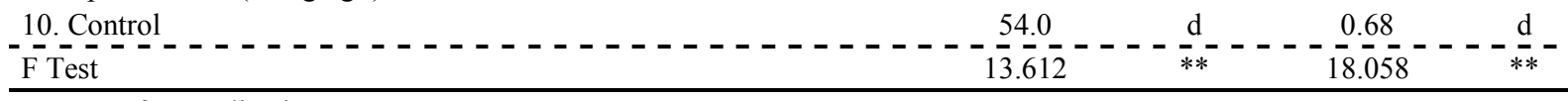 }} \\
\hline & & & & \\
\hline \multicolumn{5}{|c|}{ Days after application } \\
\hline 0 & & 18.7 & 0.25 & a \\
\hline 7 & & 25.7 & 0.33 & \\
\hline 14 & & 26.5 & 0.34 & to \\
\hline 21 & & 31.2 & 0.40 & \\
\hline $28 \ldots$ & & 27.8 & 0.35 & - \\
\hline F Test & & $\overline{5} . \overline{4} \overline{7}$ & 4.996 & \\
\hline \multicolumn{2}{|c|}{ Interaction (Treatment $\times$ Days after application) } & $\overline{1.052}---\cdot$ & $\overline{1 .} \overline{10} \overline{3}$ & \\
\hline CV (\%) & & 32.88 & 10.87 & \\
\hline
\end{tabular}

The data of incidence and severity of citrus black spot were transformed according to the equations, $x^{\prime}=\operatorname{arcsen} \sqrt{x / 100}$, and $x^{\prime}=\sqrt{x+0.5}$, respectively. Means followed by the same letter in the columns do not differ by the Scott-Knott test at $5 \%$ probability of error. $* *=$ significant by the analysis of variance at $1 \%$ probability of error; ns $=$ not significant by the analysis of variance at $5 \%$ probability of error.

\section{Experiment II}

According to the first evaluations, in August, the highest cupric fungicide rates were significantly more efficient to reduce the CBS incidence (Table $3)$. However, they did not necessarily represent the same metallic copper rate (Table 1), contradicting the recommendation by equivalence (SILVA 
JÚNIOR et al., 2016). These data showed that the rate should be specific for each cupric fungicide source, and cannot be generalized or equalized by the equivalent metallic copper. These differences were less pronounced over the evaluations, although a high effectiveness had been maintained. The CBS incidence in the control treatment varied from $44 \%$ to $94 \%$ from the first $(10 / 08)$ to the last evaluation $(14 / 11)$, while in the most efficient chemical treatment it varied from $28 \%$ to $77 \%$. These are similar results to those found by Scalloppi et al. (2012), who found that better responses are dependent on the simultaneous use of different alternatives, including fungicide with different properties from protectors and cultural practices that reduce the inoculum, thus, reducing the CBS incidence and severity.

Table 3. Incidence of citrus black spot (Phyllosticta citricarpa) in orange fruits of the Pera cultivar treated with different cupric fungicides rates and sources in the 2015/2016 crop season.

\begin{tabular}{|c|c|c|c|c|c|}
\hline \multirow[b]{2}{*}{ Treatments } & \multirow{2}{*}{$\begin{array}{l}\text { Rate } \\
\text { g } 100 \mathrm{~L}^{-1}\end{array}$} & \multicolumn{4}{|c|}{ Incidence } \\
\hline & & $\begin{array}{c}\text { Evaluation } 1 \\
08 / 10 / 2016\end{array}$ & $\begin{array}{c}\text { Evaluation } 2 \\
09 / 08 / 2016\end{array}$ & $\begin{array}{c}\text { Evaluation } 3 \\
10 / 06 / 2016\end{array}$ & $\begin{array}{c}\text { Evaluation } 4 \\
11 / 14 / 2016\end{array}$ \\
\hline Copper hydroxide $\left(538 \mathrm{~g} \mathrm{~kg}^{-1}\right)$ & 125.0 & $22.0 \mathrm{a}$ & $33.1 \mathrm{a}$ & $46.0 \mathrm{a}$ & $67.3 \mathrm{a}$ \\
\hline Copper hydroxide (538 $\left.\mathrm{g} \mathrm{kg}^{-1}\right)$ & 100.0 & $32.8 \mathrm{~b}$ & $42.0 \quad \mathrm{a}$ & $52.3 \mathrm{a}$ & $81.5 \mathrm{~b}$ \\
\hline Copper hydroxide $\left(538 \mathrm{~g} \mathrm{~kg}^{-1}\right)$ & 75.0 & $42.3 \mathrm{~b}$ & $43.8 \mathrm{a}$ & $46.3 \mathrm{a}$ & $77.0 \mathrm{a}$ \\
\hline Copper oxychloride $\left(840 \mathrm{~g} \mathrm{~kg}^{-1}\right)$ & 200.0 & $23.0 \mathrm{a}$ & $36.5 \mathrm{a}$ & $51.0 \mathrm{a}$ & $73.0 \mathrm{a}$ \\
\hline Copper oxychloride $\left(840 \mathrm{~g} \mathrm{~kg}^{-1}\right)$ & 180.0 & $22.0 \mathrm{a}$ & $36.7 \mathrm{a}$ & $52.8 \mathrm{a}$ & 73.0 \\
\hline Copper oxychloride $\left(840 \mathrm{~g} \mathrm{~kg}^{-1}\right)$ & 135.0 & $40.3 \mathrm{~b}$ & $48.0 \mathrm{~b}$ & $56.5 \mathrm{a}$ & 88.8 \\
\hline Cuprous oxide $\left(860 \mathrm{~g} \mathrm{~kg}^{-1}\right)$ & 120.0 & $33.3 \mathrm{~b}$ & $36.5 \mathrm{a}$ & $40.8 \mathrm{a}$ & 72.5 \\
\hline Cuprous oxide $\left(860 \mathrm{~g} \mathrm{~kg}^{-1}\right)$ & 75.0 & $38.8 \mathrm{~b}$ & $41.3 \mathrm{a}$ & $44.5 \mathrm{a}$ & 74.5 \\
\hline Cuprous oxide $\left(860 \mathrm{~g} \mathrm{~kg}^{-1}\right)$ & 56.3 & $46.6 \mathrm{~b}$ & $49.6 \mathrm{~b}$ & $53.3 \mathrm{a}$ & $87.0 \mathrm{~b}$ \\
\hline Control & & $44.4 \mathrm{~b}$ & 58.4 & $72.8 \mathrm{~b}$ & 94.3 \\
\hline F Test & & $6.563 * *$ & $8.11 * *$ & $3.964 * *$ & 2.92 \\
\hline CV (\%) & & 8.40 & 6.40 & 12.31 & 39.10 \\
\hline
\end{tabular}

The data of incidence of citrus black spot were transformed according to the equation $x^{\prime}=\operatorname{arcsen} \sqrt{x / 100}$. Means followed by the same letter in the columns do not differ by the Scott-Knott test at $5 \%$ probability of error. $* *=$ significant by the analysis of variance at $1 \%$ probability of error; $*=$ significant by the analysis of variance at $5 \%$ probability of error.

The treatments had no effect on the CBS severity (Table 4); the CBS severity increased even in plots treated with fungicide. No treatment completely controlled the CBS. The fungicides and rates presented no differences for the control of CBS; they were different only from the control treatment.

Table 4. Severity of citrus black spot (Phyllosticta citricarpa) in orange fruits of the Pera cultivar treated with different cupric fungicides rates and sources in the 2015/2016 crop season.

\begin{tabular}{|c|c|c|c|c|c|}
\hline \multirow[b]{2}{*}{ Treatments } & \multirow{2}{*}{$\begin{array}{c}\text { Rate } \\
\text { g } 100 \mathrm{~L}^{-1} \\
\end{array}$} & \multicolumn{4}{|c|}{ Severity } \\
\hline & & Evaluation 1 & Evaluation 2 & Evaluation 3 & Evaluation 4 \\
\hline 1. Copper hydroxide $\left(538 \mathrm{~g} \mathrm{~kg}^{-1}\right)$ & 125.0 & $0.3 \mathrm{a}$ & $0.4 \mathrm{a}$ & $0.6 \mathrm{a}$ & $0.9 \quad \mathrm{a}$ \\
\hline 2. Copper hydroxide $\left(538 \mathrm{~g} \mathrm{~kg}^{-1}\right)$ & 100.0 & $0.4 \mathrm{~b}$ & $0.6 \mathrm{~b}$ & $0.8 \mathrm{a}$ & $1.1 \mathrm{a}$ \\
\hline 3. Copper hydroxide $\left(538 \mathrm{~g} \mathrm{~kg}^{-1}\right)$ & 75.0 & $0.6 \mathrm{~d}$ & $0.6 \mathrm{~b}$ & $0.7 \mathrm{a}$ & $1.2 \mathrm{a}$ \\
\hline 4. Copper oxychloride $\left(840 \mathrm{~g} \mathrm{~kg}^{-1}\right)$ & 200.0 & $0.2 \mathrm{a}$ & $0.4 \mathrm{a}$ & $0.6 \mathrm{a}$ & 0.9 a \\
\hline 5. Copper oxychloride $\left(840 \mathrm{~g} \mathrm{~kg}^{-1}\right)$ & 180.0 & $0.3 \mathrm{a}$ & $0.5 \mathrm{a}$ & $0.7 \mathrm{a}$ & $1.0 \mathrm{a}$ \\
\hline 6. Copper oxychloride $\left(840 \mathrm{~g} \mathrm{~kg}^{-1}\right)$ & 135.0 & $0.4 \mathrm{~b}$ & $0.6 \mathrm{~b}$ & $0.8 \mathrm{a}$ & $1.1 \mathrm{a}$ \\
\hline 7. Cuprous oxide $\left(860 \mathrm{~g} \mathrm{~kg}^{-1}\right)$ & 120.0 & $0.4 \mathrm{~b}$ & $0.4 \mathrm{a}$ & $0.5 \mathrm{a}$ & 0.9 a \\
\hline 8. Cuprous oxide $\left(860 \mathrm{~g} \mathrm{~kg}^{-1}\right)$ & 75.0 & $0.5 \mathrm{c}$ & $0.5 \mathrm{~b}$ & $0.6 \mathrm{a}$ & $1.0 \mathrm{a}$ \\
\hline 9. Cuprous oxide $\left(860 \mathrm{~g} \mathrm{~kg}^{-1}\right)$ & 56.3 & $0.6 \mathrm{~d}$ & $0.6 \mathrm{~b}$ & $0.7 \quad \mathrm{a}$ & $1.1 \mathrm{a}$ \\
\hline 10. Control & & $0.7 \mathrm{~d}$ & $0.9 \mathrm{c}$ & $1.1 \mathrm{~b}$ & $1.9 \mathrm{~b}$ \\
\hline F Test & & $16.21 * *$ & $11.11 * *$ & $4.08 * *$ & $8.15 * *$ \\
\hline CV (\%) & & 4.01 & 3.98 & 6.55 & 6.12 \\
\hline
\end{tabular}

The data of severity of citrus black spot were transformed according to the equation $x^{\prime}=\sqrt{x / 0.5}$. Means followed by the same letter in the columns do not differ by the Scott-Knott test at $5 \%$ probability of error. $* *=$ significant by the analysis of variance at $1 \%$ probability of error. 
The initial cupric fungicide applications by spraying were essential to control CBS, since the control treatment without application of cupric fungicides presented higher CBS incidence and severity (Table 5).

According to the area under the disease progress curve (AUDPC) for CBS incidence, only the lowest rates of copper oxychloride

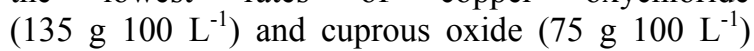

presented significant lower efficiency, increasing the CBS incidence (Table 5). The AUDPC for CBS severity showed that all the treatments were significantly different, and that they were different from the control treatment. Regarding the copper hydroxide, only the highest rate $\left(125{\left.\mathrm{~g} 100 \mathrm{~L}^{-1}\right) \text { was }}^{-1}\right.$ equivalent to the best treatments; the intermediate and highest rates of copper oxychloride and cuprous oxide presented the best results of control.

Table 5. Area under the disease progress curve (AUDPC) for incidence and severity of citrus black spot (Phyllosticta citricarpa) and yield of orange plants of the Pera cultivar as a function of cupric fungicides rates and sources, in the 2015/2016 crop season.

\begin{tabular}{|c|c|c|c|c|c|c|}
\hline \multirow[b]{2}{*}{ Treatments } & \multirow{2}{*}{$\begin{array}{l}\text { Rate } \\
\text { g } 100 \mathrm{~L}^{-1}\end{array}$} & \multicolumn{3}{|c|}{ AUDPC } & \multicolumn{2}{|c|}{$\begin{array}{c}\begin{array}{c}\text { Orange } \\
\text { yield }\end{array} \\
\end{array}$} \\
\hline & & $\begin{array}{c}\text { Incidenc } \\
(\%)\end{array}$ & & $\begin{array}{l}\text { Disease } \\
\text { index }\end{array}$ & $\begin{array}{l}\text { Kg plant }^{-1} \\
11 / 30 / 201\end{array}$ & \\
\hline Copper hydroxide $\left(538 \mathrm{~g} \mathrm{~kg}^{-1}\right)$ & 125.0 & 4114.6 & $\mathrm{a}$ & $52.3 \mathrm{a}$ & 70.9 & \\
\hline Copper hydroxide (538 $\left.\mathrm{g} \mathrm{kg}^{-1}\right)$ & 100.0 & 5011.8 & $\mathrm{a}$ & $68.6 \mathrm{~b}$ & 68.6 a & \\
\hline Copper hydroxide $\left(538 \mathrm{~g} \mathrm{~kg}^{-1}\right)$ & 75.0 & 4911.7 & $\mathrm{a}$ & $74.1 \mathrm{~b}$ & 49.9 a & $\mathrm{a}$ \\
\hline Copper oxychloride $\left(840 \mathrm{~g} \mathrm{~kg}^{-1}\right)$ & 200.0 & 4504.4 & a & $53.7 \mathrm{a}$ & 75.4 & $\mathrm{a}$ \\
\hline Copper oxychloride $\left(840 \mathrm{~g} \mathrm{~kg}^{-1}\right)$ & 180.0 & 4555.4 & $\mathrm{a}$ & $60.1 \mathrm{a}$ & $77.0 \mathrm{a}$ & \\
\hline Copper oxychloride $\left(840 \mathrm{~g} \mathrm{~kg}^{-1}\right)$ & 135.0 & 5574.4 & $\mathrm{~b}$ & $71.7 \mathrm{~b}$ & 62.3 & $\mathrm{a}$ \\
\hline Cuprous oxide $\left(860 \mathrm{~g} \mathrm{~kg}^{-1}\right)$ & 120.0 & 4301.6 & $\mathrm{a}$ & $51.5 \mathrm{a}$ & 68.7 & $\mathrm{a}$ \\
\hline Cuprous oxide $\left(860 \mathrm{~g} \mathrm{~kg}^{-1}\right)$ & 75.0 & 4682.4 & a & $60.8 \mathrm{a}$ & 61.7 & $\mathrm{a}$ \\
\hline Cuprous oxide $\left(860 \mathrm{~g} \mathrm{~kg}^{-1}\right)$ & 56.3 & 5571.1 & $\mathrm{~b}$ & $69.2 \mathrm{~b}$ & 69.4 & $\mathrm{a}$ \\
\hline Control & & 6584.1 & $\mathrm{c}$ & $108.8 \mathrm{c}$ & 58.2 & $\mathrm{a}$ \\
\hline F Test & & 5.70 & $* *$ & $9.02 * *$ & $0.40 \quad \mathrm{r}$ & $\mathrm{ns}$ \\
\hline $\mathrm{CV}(\%)$ & & 6.17 & & 7.88 & 39.46 & \\
\hline
\end{tabular}

The data of incidence and severity of citrus black spot were transformed according to the equations $x^{\prime}=\operatorname{arcsen} \sqrt{x / 100}$, and $x^{\prime}=\sqrt{x+0.5}$, respectively. Means followed by the same letter in the columns do not differ by the Scott-Knott test at $5 \%$ probability of error. ${ }^{* *}=$ significant by the analysis of variance at $1 \%$ probability of error; $n s=$ not significant by the analysis of variance at $5 \%$ probability of error.

As in Experiment I, the results of Experiment II showed no equivalence in metallic copper rate in the treatments with the best control of CBS. The

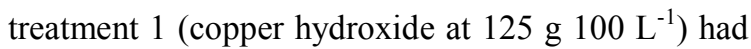
the lower metallic copper concentration in the

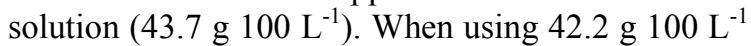
with cuprous oxide, the results were significantly lower. These were similar results to those found by Feichtenberger et al. (2001), who found equivalence of control between cupric fungicides using a high rate of metallic copper $\left(90 \mathrm{~g}\right.$ of $\left.\mathrm{Cu}^{++} 100 \mathrm{~L}^{-1}\right)$.

The orange yield presented no significant differences (Table 5). The sequence of the experiment with applications of azoxystrobin maintained the CBS severity at lower levels in the control treatment, presenting no yield losses, but losses in the fruit aesthetical quality, which were not suited for marketing as fresh fruits.

Significant linear responses of the CBS were found for all fungicide treatments, indicating that the better control levels of CBS are achieved with the use of increasing rates of $\mathrm{Cu}^{++}$(Table 6 and Figure 1). However, this result makes unfeasible the determination of the threshold for control of CBS and maximum fungicide rate, within the range of rates established for this experiment.

Table 6. Regression by analysis of variance of the area under the disease progress curve (AUDPC) for citrus black spot (Phyllosticta citricarpa) in orange plants of the Pera cultivar, for each cupric fungicide as a function of the rate used, in the 2015/2016 crop season.

\begin{tabular}{lccccc}
\hline Cupric fungicide & $\begin{array}{c}\text { Equation } \\
\text { model }\end{array}$ & Equation & CV (\%) & F Test & $\mathrm{R}^{2}$ \\
\hline Copper hydroxide & Linear & $y=-1.2523 x+108.79$ & 20.69 & $27.178^{* *}$ & $98.80 \%$ \\
Copper oxychloride & Linear & $y=-0.5431 x+108.82$ & 15.38 & $56.837^{* *}$ & $99.98 \%$ \\
Cuprous oxide & Linear & $y=-0.6483 x+103.14$ & 14.84 & $60.386^{* *}$ & $91.85 \%$ \\
\hline
\end{tabular}



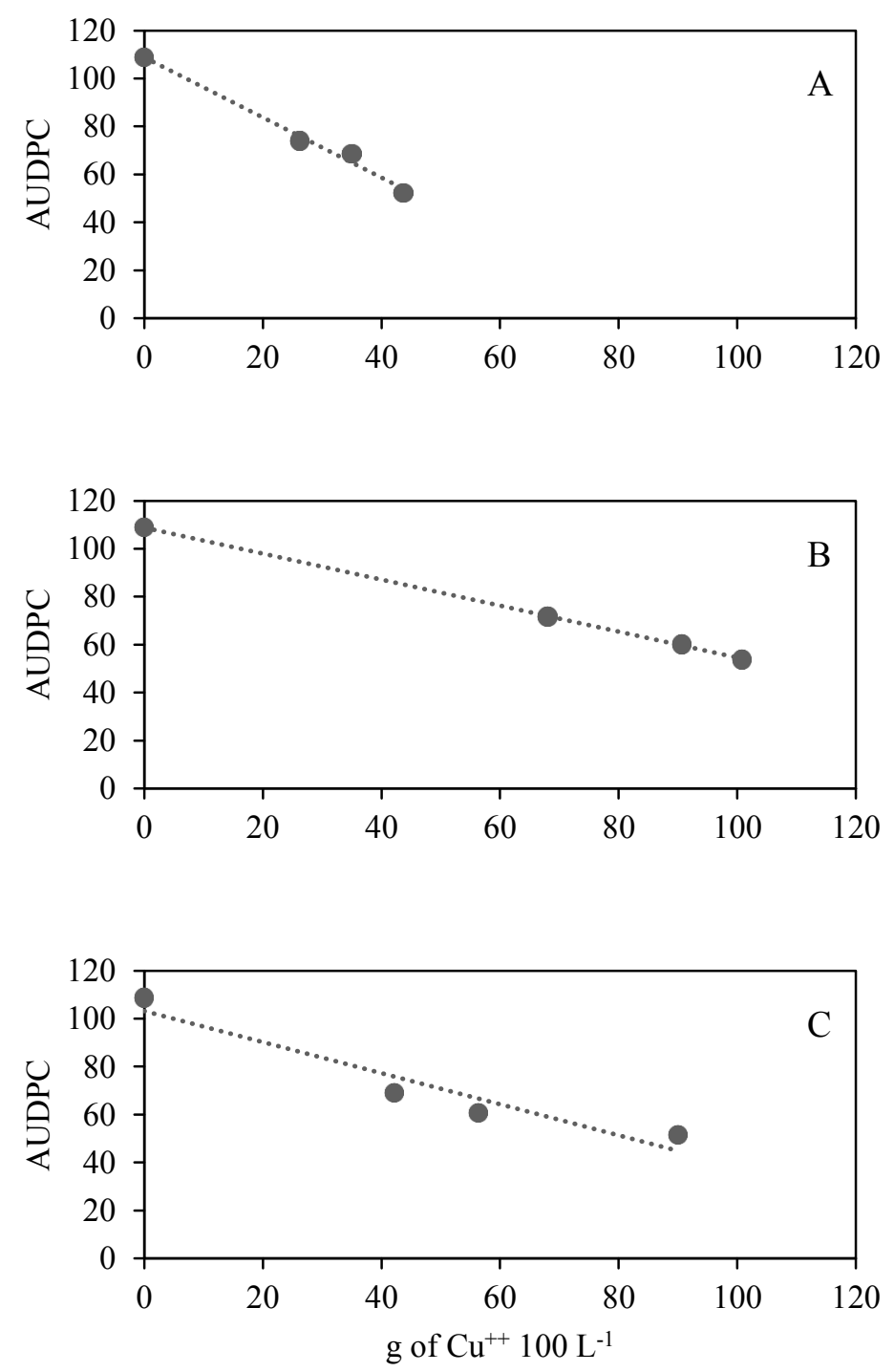

$\mathrm{A}=$ Copper hydroxide; $\mathrm{B}=$ Copper oxychloride; $\mathrm{C}=$ cuprous oxide

Figure 1. Graph of the linear regression model for the area under the disease progress curve (AUDPC) for citrus black spot (Phyllosticta citricarpa) in orange of the Pera cultivar, for each cupric fungicide as a function of the metal rate copper used, in the $2015 / 2016$ crop season.

\section{CONCLUSION}

The fungicides copper hydroxide, copper oxychloride, and cuprous oxide at rates of 43.7, 90.7, and $56.3 \mathrm{~g} \mathrm{of} \mathrm{Cu}^{++} 100 \mathrm{~L}^{-1}$, respectively, are efficient and present similar results for the control of citrus black spot when applied with 21-day intervals and before applications of strobilurin fungicides.

The fungicides copper hydroxide, copper oxychloride, and cuprous oxide at rates of 43.7, 90.7 and $90 \mathrm{~g}$ of $\mathrm{Cu}^{++} 100 \mathrm{~L}^{-1}$, respectively, can control protectively citrus fruits from infections with Phyllosticta citricarpa up to 28 days.

\section{REFERENCES}

AGUIAR, R. L. et al. Período de incubação de Guignardia citricarpa em diferentes estádios fenológicos de frutos de laranjeira 'Valência'. Tropical Plant Pathology, 37: 155-158, 2012.

ALMEIDA, T. F.; REIS, R. F.; GOES, A. Method of inoculation of Guignardia citricarpa (Phyllosticta citricarpa) on 'Pêra Rio' sweet orange fruit. In: IX INTERNATIONAL CONGRESS OF PLANT PATHOLOGY, 2008, Torino. Proceedings... 2008. International Society for Plant Pathology, 2008. 1: $158-159$.

BALDASSARI, R. B.; WICKERT, E.; GOES, A. Pathogenicity, colony morphology and diversity of isolates of Guignardia citricarpa and G. mangiferae isolated from Citrus spp. Europe Journal Plant Pathology, 120: 103-110, 2008.

BRASIL. Ministério da Agricultura, pecuária e Abastecimento - MAPA. AGROFIT - Sistema de 
Agrotóxicos Fitossanitários. Disponível em: $<$ http://agrofit.agricultura.gov.br/agrofit_cons/ principal_agrofit_cons>. Acesso em: 24 mai. 2017.

European and Mediterranean Plant Protection Organization - EPPO. PQR-EPPO data base on quarantine pests. 2017. Disponível em: <http:// www.eppo.int/DATABASES/pqr/pqr.htm>. Acesso em: 30 ago. 2017.

FEICHTENBERGER, E. et al. Competição de fungicidas à base de cobre no controle da mancha preta (Guignardia citricarpa) em laranjeiras 'Folha Murcha'. Fitopatologia Brasileira, 26: 444-449, 2001.

HIDALGO G.; PÉREZ V. L. Diferenciación morfológica, cultural y biológica de Guignardia citricarpa y Guignardia mangiferae en frutos cítricos de Cuba. Fitosanidad, 14: 141-152, 2010.

IKEDA, M. Efeito de fungicidas do grupo químico das estrobilurinas no controle da mancha preta dos citros, na produção e na qualidade tecnológica dos frutos. 2011. 35 f. Dissertação (Mestrado em Agronomia: Área de Concentração em Produção Vegetal) - Faculdade de Ciências Agrárias e Veterinárias, Unesp, Jaboticabal, 2011.

KOTZÉ, J. M. Citrus black spot. In: TIMMER, L.W.; GARNSEY, S. M.; GRAHAM, J. H. (Eds.). Compendium of Citrus Diseases. St. Paul, MN: The American Phytopathological Society, 2000. v. 2, cap. 6, p. 595-634.

MOTTA, R. R. Determinação do período residual de fungicidas protetor e sistêmico para o controle de Guignardia citricarpa em frutos cítricos. 2009. 84 f. Dissertação (Mestrado em Agronomia: Área de Concentração em Produção Vegetal) - Faculdade de Ciências Agrárias e Veterinárias, Unesp, Jaboticabal, 2009.

SCALOPPI, E. M. T. et al. Efeito do manejo cultural e químico na incidência e severidade da manchapreta dos citros. Revista Brasileira de Fruticultura, 34: 102-108, 2012.

SCHUBERT, T. et al. Citrus Black Spot (Guignardia citricarpa) Discovered in Florida. 2010. Disponível em: <www.doacs.state.fl.us/pi/ pest_alerts/pdf/citrus-black-spotpest-alert.pdf $>$.

Acesso em: 22 mai. 2017.

SILVA JUNIOR, G. J. et al. Pinta preta: a doença e seu manejo. Araraquara, SP: Fundecitrus, 2016. 208 p.
SPÓSITO, M. B. et al. Elaboração e validação de escala diagramática para avaliação da severidade da mancha preta em frutos cítricos. Fitopatologia Brasileira, 29: 81-85, 2004.

STOLLER DO BRASIL LTDA. Guia de fases de desenvolvimento: Citros. 1. ed. Cosmópolis, SP, 2010. 4 p.

TIMMER, L. W.; GARNSEY, S. M.; GRAHAM, J. $\mathrm{H}$. Compendium of Citrus Diseases. 2. ed. Lake Alfred, FL: IFLA, 2000, 92 p.

VINHAS, T. Controle químico da Guignardia citricarpa, agente causal da mancha preta dos citros em frutos de laranja 'Valência'. 2011. $41 \mathrm{f}$. Dissertação (Mestrado em Agronomia: Área de Concentração em Master Citrus) - Fundo de Defesa da Citricultura, Araraquara, 2011.

WHEELER, B. E. J. An introduction to plant disease. London: John Wiley \& Sons, 1969. 374 p. 